\title{
Instrumental color and sensory acceptance of soy-based emulsions: a response surface approach
}

\author{
Cor instrumental e aceitação sensorial de emulsões à base de soja: \\ uma abordagem através da metodologia de superfície de resposta
}

Daniel GRANATO $^{1 \star}$, Maria Lucia MASSON ${ }^{1}$

\begin{abstract}
Response Surface Methodology (RSM) was applied to evaluate the chromatic features and sensory acceptance of emulsions that combine Soy Protein (SP) and red Guava Juice (GJ). The parameters analyzed were: instrumental color based on the coordinates $a^{\star}$ (redness), $b^{\star}$ (yellowness), $L^{\star}$ (lightness), $C^{\star}$ (chromaticity), $h^{\star}$ (hue angle), visual color, acceptance, and appearance. The analyses of the results showed that GJ was responsible for the high measured values of red color, hue angle, chromaticity, acceptance, and visual color, whereas SP was the variable that increased the yellowness intensity of the assays. The redness $\left(\mathrm{R}^{2}{ }_{\text {adj }}=74.86 \%, \mathrm{p}<0.01\right)$ and hue angle $\left(\mathrm{R}_{\text {adj }}^{2}=80.96 \%, \mathrm{p}<0.01\right)$ were related to the independent variables by linear models, while the sensory data (color and acceptance) could not be modeled due to a high variability. The models of yellowness, lightness, and chromaticity did not present lack of fit but presented adjusted determination coefficients bellow 70\%. Notwithstanding, the linear correlations between sensory and instrumental data were not significant $(p>0.05)$ and low Pearson coefficients were obtained. The results showed that RSM is a useful tool to develop soy-based emulsions and model some chromatic features of guava-based emulsions through RSM.
\end{abstract}

Keywords: colorimetry; response surface methodology; sensory acceptability, functional foods; Glycine max.

\section{Resumo}

A Metodologia de Superfície de Resposta (MSR) foi aplicada para avaliar as características cromáticas de emulsões compostas de Proteína de Soja (PS) e Suco de Goiaba vermelha (SG). Os parâmetros analisados foram: cor instrumental baseada nas coordenadas $a^{\star}$ (vermelho), $b^{\star}$ (amarelo), $L^{\star}$ (luminosidade), $C^{\star}$ (cromaticidade), $h^{\star}$ (tonalidade), cor, aceitação e aparência. As análises dos resultados mostraram que o SG foi responsável pelos altos valores de cor vermelha, tonalidade, cromaticidade, aceitação e cor, ao passo que a PS aumentou a cor amarela das emulsões. O parâmetro de cor vermelha $\left(\mathrm{R}_{\text {adj }}^{2}=74,86 \%, \mathrm{p}<0,01\right)$ e a tonalidade de cor $\left(\mathrm{R}_{\text {adj }}^{2}=80,96 \%, \mathrm{p}<0,01\right)$ apresentaram alto grau de correlação linear com as proporções de SP e SG adicionadas às emulsões; ao passo que os resultados da análise sensorial (aceitação e cor) não puderam ser modelados devido à grande variabilidade dos resultados. Os modelos de cor amarela, luminosidade, e cromaticidade não apresentaram falta de ajuste, mas seus coeficientes de determinação ajustados não foram superiores a 70\%. Não obstante, as correlações entre os dados sensoriais e cromáticos não foram significativas ( $\mathrm{p}>0,05)$, obtendo-se baixos coeficientes de Pearson. A análise dos resultados indicou que a MSR é uma técnica útil no desenvolvimento de emulsões à base de soja e pode ser usada para modelar alguns parâmetros cromáticos de emulsões elaboradas com SG.

Palavras-chave: colorimetria; alimentos funcionais; propriedades físicas; Glycine max.

\section{Introduction}

Color is one of the major attributes which affects the consumer perception of quality (HUTCHINGS, 2005), holds a preeminent position in food acceptance, and can be a predictor of non sensory attributes like moisture content, over-processing, and pigment content (HEREDIA et al., 2008; MELÉNDEZMARTÍNEZ et al., 2008). It can also be used as a direct quality estimate of fruits, beverages, oils, and even non-dairy emulsions (HEREDIA et al., 2007, 2008; GRANATO, 2009).

Color perception interacts with other sensory attributes such as sweetness, creaminess, flavor, and overall acceptance (HUTCHINGS, 1999), which makes sensory analysis an important tool in food characterization. In this regard, the application of colorimetry offers an objective way of color assessment because it is based on the whole visible spectrum and makes it possible to obtain the real chromatic profile of food products (OSORIO et al., 2007). Research on color of food, its chemistry, and the factors that can alter it has been and continue to be the subject of a significant part of food research literature once food color measurement has been used as a tool to follow the change of a product and to determine relationships with other food qualities such as acceptance, visual color, and appearance (HUTCHING, 2005; GALLO et al., 2009).

The methodology of color measurement is a mature science and any food product can be measured (HUNT, 2001). The

Recebido para publicação em 19/3/2009

Aceito para publicação em 18/7/2009 (004114)

1 Programa de Pós-graduação em Tecnologia de Alimentos, Setor de Tecnologia, Universidade Federal do Paraná - UFPR, CP 19011, CEP 81531-990, Jardim das Américas,

Curitiba - PR, Brasil,E-mail: mestradoalimentos@gmail.com

${ }^{*}$ A quem a correspondência deve ser enviada 
objective measurement of color is of great importance for food producers due to the relationship existing between color and the acceptability (CALVO; SALVADOR; FISZMAN, 2001), which has propelled the development of techniques and apparatus suitable for that purpose in the last decades (YAM; PAPADAKIS, 2004; MELÉNDEZ-MARTÍNEZ; VICARIO; HEREDIA, 2005). In this regard, there is currently a growing tendency to relate the color coordinates to the levels of food acceptance, which is an interesting approach amenable to be harnessed for quality control purposes since the interest for determining how well the product is accepted by potential consumers is increasing due to its likely connection with marketing practices and purposes (LAWLESS; HEYMANN, 1999; DUTCOSKY, 2007).

Color is a major attribute that is always evaluated by consumers when they buy foods, and it determines the purchase and regular consumption (LAWLESS; HEYMANN, 1999). Hence, in order to understand the relationship between instrumental and sensory analyses, multidimensional studies must be conducted, so more data would be available for academic bodies and industries. In Brazil, correlations between colorimetric and sensory data involving soy-based foods are scarce. Herein, the objectives of this research were: to develop palatable soy-based emulsions and to analyze the univariate correlation between instrumental color and sensory acceptance of products.

\section{Material and methods}

\subsection{Material and experimental design}

The ingredients used in the formulations included soy watersoluble extract in powder ( $40 \%$ protein), commercial sucrose, a pool of emulsifiers (distillated monoglycerides, polysorbate 60, sorbitane monoesterate), guar gum and carboximethylcelullose in a 1:1 ratio, guava natural flavoring, soy cream (18.67\% fat), oligofructose ( $95 \%$ purity), red guava juice ( $45 \%$ of pulp), and guava juice in a powder form.

A full factorial design $\left(3^{2}\right)$ containing three Centre points (C) was used (MYERS; MONTGOMERY, 2002), in which Guava Juice (GJ) and Soy Protein (SP) were the independent variables studied at three different levels. The coded $(-1,0,+1)$ and the decoded matrix values for the factors are given in Table 1 . The experiments were carried out at random in order to minimize the effect of unexplained variability in the responses due to systematic errors.

\subsection{Emulsion development}

Each lot of soy-based guava emulsion was produced at a large enough scale to obtain $3.50 \mathrm{~kg}$ of the final product. For this purpose, after individual weighing, all the ingredients were mixed using a blender for 3 minutes at 9000 r.p.m. The cream formed $(3 \mathrm{~kg})$ was heated in a water-bath until it reached $80^{\circ} \mathrm{C}$ and was kept at this temperature for 20 seconds. The desserts were placed in closed glass containers, cooled to room temperature $\left(25^{\circ} \mathrm{C}\right)$, and then stored refrigerated $\left(7^{\circ} \mathrm{C}\right)$ for 24 hours prior to their evaluation. Triplicate samples were prepared for the analyses.
The ingredients and respective quantities employed for the production of the 12 soy-based guava emulsions studied are described in Table 2. The guava juice ranged from 22 to $32 \%$, and in accordance to this criterion, each assay contained a established proportion of guava juice, as observed in Table 1.

\subsection{Color assessment}

The colorimetric study was conducted by reflectance right after the emulsification process by a spectrophotometer (Model D25L-2, Hunter Assoc. Laboratory, Reston, VA, USA). The specular component included mode was selected because it estimates the real color of the trials. It was considered the CIELAB uniform space, in which two color coordinates, $a^{*}$ and $b^{*}$, as well as a psychometric index of lightness, $L^{*}$, were measured. The parameter $a^{*}$ takes positive values for reddish colors and negative values for the greenish ones, whereas $b^{*}$ takes positive values for yellowish colors and negative values for the bluish ones. $L^{*}$ is an approximate measurement of luminosity, which is the property according to which each color can be considered as equivalent to a member of the grey scale, between black and white, taking values within the range $0-100$ (MACDOUGALL, 2002).

Chroma $\left(C^{*}\right)$, considered the quantitative attribute of colorfulness, is used to determine the degree of difference of a hue in comparison to a grey color with the same lightness. The higher the chroma values, the higher the color intensity of samples perceived by humans. Chroma was calculated using Equation 1:

$C^{*}=\left(a^{* 2}+b^{* 2}\right)^{1 / 2}$

Hue angle $\left(h^{*}\right)$, considered the qualitative attribute of color, is the attribute according to which colors have been traditionally defined as reddish, greenish, etc, and it is used to define the difference of a certain color with reference to grey color with the same lightness. This attribute is related to the differences in absorbance at different wavelengths. A higher hue angle represents a lesser yellow character in the assays and

Table 1. Full factorial design $\left(3^{2}\right)$ applied to the development of the soy-based emulsions.

\begin{tabular}{lrrrrr}
\hline \multirow{2}{*}{ Assays } & \multicolumn{2}{c}{ Coded matrix } & & \multicolumn{2}{c}{ Decoded matrix } \\
\cline { 2 - 3 } \cline { 5 - 6 } & GJ & SP & & GJ $(\%)$ & SP $(\%)$ \\
\hline 1 & -1.00 & -1.00 & & 22 & 1.00 \\
2 & -1.00 & 0.00 & & 22 & 2.00 \\
3 & -1.00 & 1.00 & & 22 & 3.00 \\
4 & 0.00 & -1.00 & & 27 & 1.00 \\
5 & 0.00 & 0.00 & & 27 & 2.00 \\
6 & 0.00 & 1.00 & & 27 & 3.00 \\
7 & 1.00 & -1.00 & & 32 & 1.00 \\
8 & 1.00 & 0.00 & & 32 & 2.00 \\
9 & 1.00 & 1.00 & 32 & 3.00 \\
$10(\mathrm{C})$ & 0.00 & 0.00 & 27 & 2.00 \\
$11(\mathrm{C})$ & 0.00 & 0.00 & 27 & 2.00 \\
$12(\mathrm{C})$ & 0.00 & 0.00 & 27 & 2.00 \\
\hline
\end{tabular}

GJ, Guava Juice; SP, Soy Protein; (C), Centre point. 
a greater redness intensity. Hue angle was calculated using the Equation 2:

$h^{*}=\tan ^{-1}\left(b^{*} / a^{*}\right)$

The equations and the color measurement followed the procedures outlined by Duangmal, Saicheua and Sueeprasan, (2008). Prior to measuring the color of the emulsion samples, the spectrophotometer was calibrated using black and white reference standard ceramic plates $(\mathrm{X}=78.9, \mathrm{Y}=83.9, \mathrm{Z}=88.9)$. Assays were placed in a clear glass Petri dish, and the color measurements were performed six times, in triplicate samples.

\subsection{Sensory evaluation}

In food acceptance tests, it is typical for respondents to rate a product on overall acceptability and on a series of product attributes. In this study, the sensory panel was asked to describe the sensory attributes of appearance, color, and overall acceptance of the emulsions by assigning a liking score on a 7-point hedonic scale, where 1 = 'strongly disliked'; 2 = 'moderately disliked'; 3 = 'slightly disliked'; 4 = 'indifferent'; $5=$ 'slightly liked'; 6 = 'moderately liked' and 7 = 'strongly liked' (LAWLESS; HEYMANN, 1999). The tests were performed in individual booths lighted by a fluorescent white lamp at 10:00 a.m. Approximately $50 \mathrm{~g}$ of emulsion at $7{ }^{\circ} \mathrm{C}$ was placed in plastic cups coded with random 3-digit numbers for identification. The emulsion samples were presented monadically for each panelist. A total number of 75 different panelists evaluated each sample in different sessions, with a total of 900 responses. Unsalted crackers and mineral water were provided to cleanse the palate. The study was approved by the Federal University of Paraná Ethics Research Committee in accordance with the Resolution 196/1996 of the National Health Council.

\subsection{Data Analysis}

The results were expressed by the mean of the replicates for each response. Initially, all variables had their normality and variance homogeneity tested by dispersion graphs and Hartley's test. As a second step, one-way ANOVA was carried out for the chromatic data followed by Tukey's Honest Significant Difference (HSD) parametric test. Two-way ANOVA was carried out for the sensory data to determine the significance for the treatments and panelists followed by the parametric Tukey's HSD test (BARROS NETO et al., 2007). A p-value bellow 0.05 was considered statistically significant for all statistical analysis. Pearson products $(\mathrm{r})$ were used to evaluate the strength of correlations among sensory attributes and instrumental color parameters. The following criterion was established to analyze the strength of correlations: perfect $(r= \pm 1.00)$, strong $( \pm 0.80 \leq r< \pm 1.00)$, moderate $( \pm 0.50 \leq \mathrm{r}< \pm 0.80)$, weak $( \pm 0.10 \leq \mathrm{r}< \pm 0.50)$, and very weak correlation $(0.01 \leq \mathrm{r}< \pm 0.10)$.

The data obtained were treated using the Response Surface Methodology (RSM). The quality of the fitted models was evaluated by ANOVA based on the F-test and on the percentage of explained variance, which provides a measurement of how much of the variability in the observed response values could be explained by the experimental factors and their interactions (MYERS; MONTGOMERY, 2002). The basic model Equation used to fit the data was (Equation 3):

$\mathrm{E}(\mathrm{y})=\beta_{0}+\beta_{1} \mathrm{x}_{1}+\beta_{2} \mathrm{x}_{2}+\beta_{11} \mathrm{x}_{1}^{2}+\beta_{22} \mathrm{x}_{2}^{2}+\beta_{12} \mathrm{x}_{1} \mathrm{x}_{2}$

where $\mathrm{E}(\mathrm{y})$ is the predicted response from the colorimetric evaluation, $\beta_{0}$ is a constant, $\beta_{1}, \beta_{2}, \beta_{11}, \beta_{22}$ and $\beta_{12}$ are the regression coefficients and $\mathrm{x}_{1}$ and $\mathrm{x}_{2}$ are the levels of the independent variables. The terms found non-significant statistically $(\mathrm{p}>0.05)$ were excluded from the initial models, and the experimental data were refitted only to the significant $(\mathrm{p}<0.05)$ parameters.

To visualize the relationships between the responses and the independent variables, surface response plots of the fitted regression equations were generated using the statistical package Statistica (version 7.1, Statsoft, Tulsa, OK, USA).

\section{Results and discussion}

\subsection{Instrumental color}

Table 3 shows that the chromatic data presented homogenous variances among the samples $(p \geq 0.05)$ and statistical differences $(p<0.001)$ were obtained for all the attributes, basic requirements to RSM application. Hence, both independent variables influenced directly the color attributes of the developed emulsions. Indeed, besides lycopene, red guava juice also

Table 2. Ingredients ( $\mathrm{g} .100 \mathrm{~g}^{-1}$ ) employed for the production of the soy-based desserts

\begin{tabular}{|c|c|c|c|}
\hline Ingredients & $\begin{array}{c}\text { Base for the desserts with } \\
1 \% \text { of soy protein }\end{array}$ & $\begin{array}{c}\text { Base for the desserts with } \\
2 \% \text { of soy protein }\end{array}$ & $\begin{array}{c}\text { Base for the desserts with } \\
3 \% \text { of soy protein }\end{array}$ \\
\hline Soy extract ${ }^{1}$ & 2.50 & 5.00 & 7.50 \\
\hline Soy cream & 40.00 & 40.00 & 40.00 \\
\hline Guava juice $^{2}$ & $22-32$ & $22-32$ & $22-32$ \\
\hline Sucrose & 14.00 & 14.00 & 14.00 \\
\hline Guava flavoring & 0.15 & 0.15 & 0.15 \\
\hline Guar gum and $\mathrm{CMC}^{3}$ & 1.00 & 1.00 & 0.75 \\
\hline Emulsifying agent & 1.00 & 1.00 & 0.75 \\
\hline Guava juice in powder & 2.10 & 2.10 & 2.10 \\
\hline Oligofructose & 2.63 & 2.63 & 2.63 \\
\hline Iron sulphate & 0.0104 & 0.0104 & 0.0104 \\
\hline Water & $\mathrm{qs}^{4} 100 \mathrm{~g}$ & $\mathrm{Qs}^{4} 100 \mathrm{~g}$ & $\mathrm{qs}^{4} 100 \mathrm{~g}$ \\
\hline
\end{tabular}

${ }^{1}$ Protein content (40\%); ${ }^{2}$ Guava juice concentration ranged from 22 to $32 \% ;{ }^{3}$ carboximethylcelullose; ${ }^{4} \mathrm{qs}=$ quantum sufficit for $100 \mathrm{~g}$. 
contains zeinoxanthin, 5.8-epoxy- $\beta$-carotene and $\beta$-carotene (RODRIGUEZ-AMAYA; AMAYA-FARFAN; KIMURA, 2007), carotenoids that present a high value of chromaticity due to conjugated double bonds in their chemical molecule.

All the assays presented high values of lightness $\left(L^{*}>75.70\right)$ showing that the emulsions were bright (Table 3 ). Notwithstanding, a moderate correlation between lightness and chromaticity $(\mathrm{r}=-0.71, \mathrm{p}<0.001)$ and a weak correlation between lightness and hue angle $(r=-0.46, p=0.13)$ were observed. In addition, the assay number 7 ( $1 \%$ SP and $32 \% \mathrm{GJ})$ presented the highest red coordinate value $\left(a^{*}=14.60\right)$ and a great yellow coordinate value $\left(b^{*}=15.26\right)$ presenting thus the highest color intensity $\left(C^{\star}=21.12\right)$. The lightness data could be fitted into a linear equation, with a significant p-value $(<0.01)$, and the total explained variance was almost $69 \%$, as shown in Figure 1.

Guava juice was the main variable that increased the reddish hue ( $a^{*}$ coordinate and hue angle), as shown by the obtained values of assays number $4(27 \% \mathrm{GJ}), 7(32 \% \mathrm{GJ})$, and $8(32 \% \mathrm{GJ})$. Figures 2 and 3 show that the more juice was added in the assays, the more reddish they became. The proposed regression models for redness ( $a^{*}$ coordinate) and hue angle were significant $(\mathrm{p}<0.01)$ and did not have lack of fit $(\mathrm{p}>0.05)$. Red guava juice was responsible for increasing the values of $a^{*}$ coordinate (redness) and hue angle, while soy protein showed a tendency to decrease the redness of the assays. The adjusted determination coefficient for $a^{*}$ coordinate was $74.86 \%$, and for hue angle it was $80.96 \%$, which indicates that the regression models explained suitably the variances, thus ensuring a satisfactory fitness of response surface models to the data. Furthermore, Pearson correlations between $a^{*}$ coordinate $\times$ hue angle $(\mathrm{r}=0.90, \mathrm{p}<0.001)$, and between $a^{*}$ coordinate $\times$ chromaticity $(r=0.80, p<0.001)$ were strong, evidencing the importance of guava juice on the red hue of the emulsions.

Table 3. Colorimetric parameters of the developed soy-based emulsions

\begin{tabular}{|c|c|c|c|c|c|c|c|}
\hline \multirow[t]{2}{*}{ Assays } & \multicolumn{2}{|c|}{$\begin{array}{c}\text { Independent } \\
\text { variables }\end{array}$} & \multicolumn{5}{|c|}{ Responses $^{1}$} \\
\hline & GJ (\%) & SP (\%) & $L^{*}$ & $a^{*}$ & $b^{*}$ & $C^{*}$ & $h^{*}$ \\
\hline 1 & 22 & 1.00 & $77.68^{\mathrm{d}, \mathrm{e}}$ & $12.46^{\mathrm{e}}$ & $14.66^{\mathrm{h}}$ & $19.21^{g}$ & $1.21^{\mathrm{c}}$ \\
\hline 2 & 22 & 2.00 & $79.60^{\mathrm{a}}$ & $11.33^{\mathrm{g}}$ & $14.95^{\mathrm{f}}$ & $18.76^{\mathrm{h}}$ & $1.15^{\mathrm{h}}$ \\
\hline 3 & 22 & 3.00 & $78.59^{b}$ & $11.28^{\mathrm{g}}$ & $16.09^{\mathrm{b}}$ & $19.62^{\mathrm{e}}$ & $1.12^{\mathrm{i}}$ \\
\hline 4 & 27 & 1.00 & $77.29^{f}$ & $13.90^{\mathrm{b}}$ & $14.82^{\mathrm{g}}$ & $20.31^{c}$ & $1.27^{\mathrm{b}}$ \\
\hline 5 & 27 & 2.00 & $78.45^{c}$ & $11.89^{\mathrm{f}}$ & $15.84^{\mathrm{c}}$ & $19.69^{e}$ & $1.19^{\mathrm{e}}$ \\
\hline 6 & 27 & 3.00 & $77.73^{\mathrm{d}, \mathrm{e}}$ & $10.74^{\mathrm{h}}$ & $16.26^{\mathrm{a}}$ & $19.48^{\mathrm{f}}$ & $1.10^{\mathrm{i}}$ \\
\hline 7 & 32 & 1.00 & $76.61^{g}$ & $14.60^{\mathrm{a}}$ & $15.26^{\mathrm{e}}$ & $21.12^{\mathrm{a}}$ & $1.28^{\mathrm{a}}$ \\
\hline 8 & 32 & 2.00 & $76.11^{\mathrm{h}}$ & $13.02^{\mathrm{c}}$ & $15.47^{\mathrm{d}}$ & $20.22^{c, d}$ & $1.20^{\mathrm{d}}$ \\
\hline 9 & 32 & 3.00 & $75.74^{\mathrm{i}}$ & $12.99^{c}$ & $15.88^{c}$ & $20.54^{\mathrm{b}}$ & $1.19^{\mathrm{e}}$ \\
\hline $10(\mathrm{C})$ & 27 & 2.00 & $77.84^{\mathrm{d}}$ & $12.78^{\mathrm{d}}$ & $15.49^{\mathrm{d}}$ & $20.08^{\mathrm{d}}$ & $1.15^{\mathrm{h}}$ \\
\hline $11(\mathrm{C})$ & 27 & 2.00 & $78.20^{c}$ & $11.94^{\mathrm{f}}$ & $15.51^{\mathrm{d}}$ & $19.57^{\mathrm{e}}$ & $1.19^{\mathrm{f}}$ \\
\hline $12(\mathrm{C})$ & 27 & 2.00 & $77.54^{\mathrm{e}, \mathrm{f}}$ & $11.88^{\mathrm{f}}$ & $14.58^{\mathrm{h}}$ & $18.81^{\mathrm{h}}$ & $1.16^{\mathrm{g}}$ \\
\hline \multicolumn{3}{|c|}{ Pooled standard deviation } & 1.07 & 1.12 & 0.54 & 0.69 & 0.05 \\
\hline \multicolumn{3}{|c|}{$\mathrm{p}(\text { Hartley })^{2}$} & 0.33 & 0.36 & 0.45 & 0.10 & 0.05 \\
\hline \multicolumn{3}{|c|}{$\mathrm{p}(\mathrm{ANOVA})^{3}$} & $<0.001$ & $<0.001$ & $<0.001$ & $<0.001$ & $<0.001$ \\
\hline
\end{tabular}

SP, Soy Protein; GJ, Guava Juice; (C), Centre point; ${ }^{1}$ Values expressed as mean $(n=6)$; ${ }^{2}$ Probability values obtained by Hartley test (F max) for homogeneity of variances; ${ }^{3}$ Probability values obtained by one-way ANOVA.

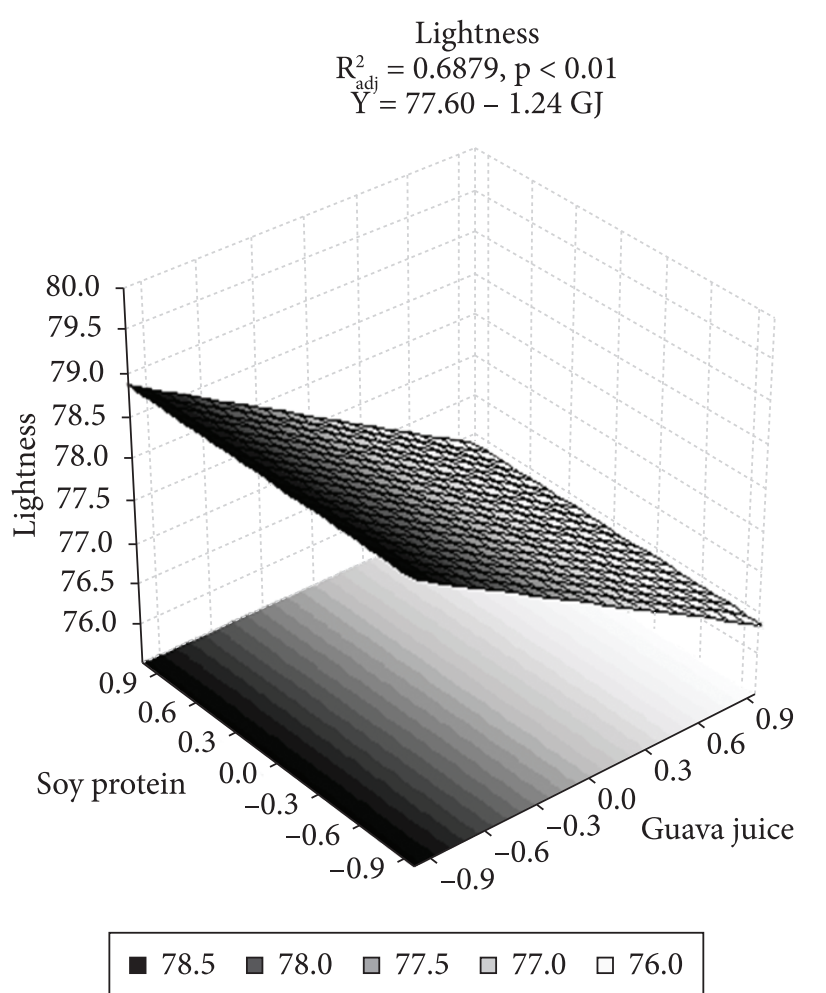

Figure 1. Effect of soy protein and red guava juice proportions on lightness of soy-based emulsions.

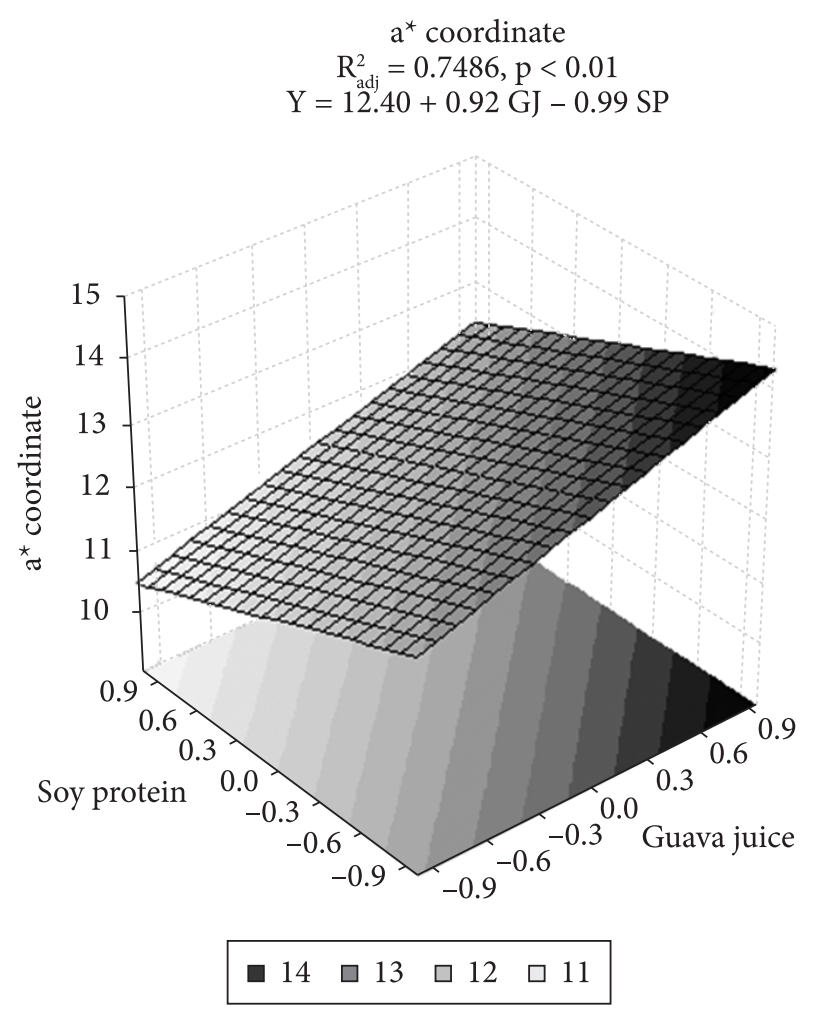

Figure 2. Effect of soy protein and red guava juice proportions on $a^{\star}$ coordinate of soy-based emulsions. 
The $b^{*}$ coordinate values ranged significantly $(\mathrm{p}<0.001)$ from 14.58 to 16.26 , and the assays number 3,6 , and 9 , which contained $3 \%$ of soy-protein presented the highest values of yellowness $\left(\mathrm{b}^{*}\right.$ coordinate). The data were fitted into a linear equation, with a significant $\mathrm{p}$-value $(\mathrm{p}<0.01)$; nonetheless, the adjusted determination coefficient was low (54.69\%). Hence, this model can only be used for checking the tendency of the data and cannot be a purpose-predictor. In practice, low values of $\mathrm{R}_{\text {adj }}^{2}$ (bellow 70\%) are indicators of non-adequacy of models to describe the influence of the independent variables on the responses (NATH; CHATTOPADHYAY, 2007).

From the above, it can be concluded that the models for the $a^{*}$ coordinate and hue angle represent the data for the responses obtained and were deemed suitable to be used as purposepredictors and to navigate the experimental design space.

\subsection{Sensory data}

A comparison of the rating tests for the evaluated emulsion samples from all subjects taking part in the study is shown in Table 4. All samples presented mean hedonic scores within the acceptability region (scores equal or above 5.00) for appearance, but assays number 2 (22\% GJ and 2\% SP) and 3 (22\% GJ and $3 \% \mathrm{SP}$ ) garnered mean hedonic scores bellow 5.00 for acceptance and color, respectively. Assay number 7 (32\% GJ and 1\% SP) presented the highest mean hedonic scores for visual color and appearance. Nonetheless, this score was not significant $(\mathrm{p}<0.05)$ compared to most part of the assays.
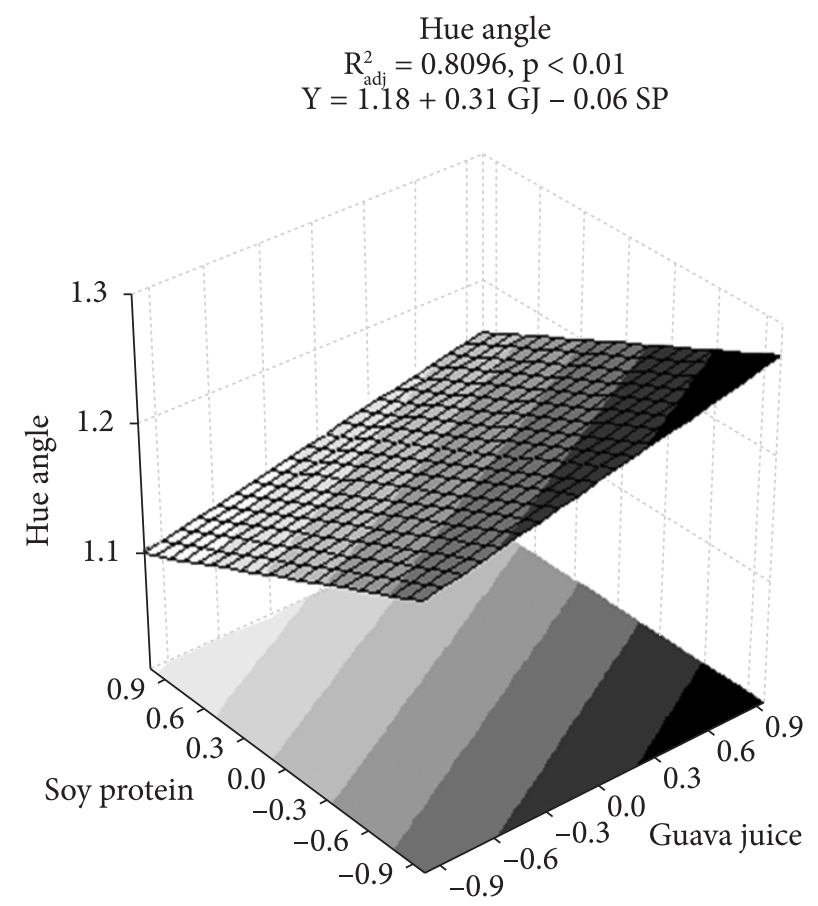

ロ $1.28 \square 1.25 \quad \square \quad 1.20 \quad \square \quad 1.15 \quad \square 1.10$

Figure 3. Effect of soy protein and red guava juice proportions on hue angle of soy-based emulsions.
Assays number 6 (6.00), 7 (5.61), and 8 (5.96) garnered the highest acceptance scores indicating that even emulsions containing higher concentrations of soy extract were well accepted by the taste panel. The linear correlation between acceptance and color $(\mathrm{r}=0.53, \mathrm{p}=0.08)$, and appearance $(\mathrm{r}=0.56, \mathrm{p}=0.07)$ was moderate and non-significant.

Food acceptance is not the only parameter that industries evaluate when a new product is processed; other food attributes such as flavor, creaminess, taste, color, acidity, and sweetness are also assessed by sensory evaluation in order to ascertain the overall acceptance of the product (POPPER et al., 2004). Thus, the combined analysis of physicochemical, chromatic, rheological, sensory, and statistical results is a good tool that can guide the company to choose the representative product with suitable features to be further optimized and later commercially explored (GRANATO; ELLENDERSEN, 2009).

A non-dairy frozen emulsion containing soy isolate protein, coconut milk, and strawberry cheesecake flavoring received $96.33 \%$ of acceptance and $82.57 \%$ of purchase intent indicating that consumers were beginning to overcome the negative opinions they once held regarding soy-containing products and were willing to purchase these foods not only due to the health benefits they may confer, but also because of their good taste (SOLER, 2005). Behrens, Roig and Silva (2004) developed soymilk products and registered suitable scores of acceptance and flavor for the beverages concluding that it is possible to formulate highly acceptable soy-based products with the addition of flavorings.

$$
\begin{gathered}
\text { Appearance } \\
\mathrm{R}_{\text {add }}^{2}=0.7516, \mathrm{p}<0.001 \\
\mathrm{Y}=5.36+0.15 \mathrm{G}+0.20 \mathrm{SP}^{2}-0.16 \mathrm{GJ} \mathrm{SP}-\mathrm{GJ}^{2} \mathrm{SP}^{2}
\end{gathered}
$$

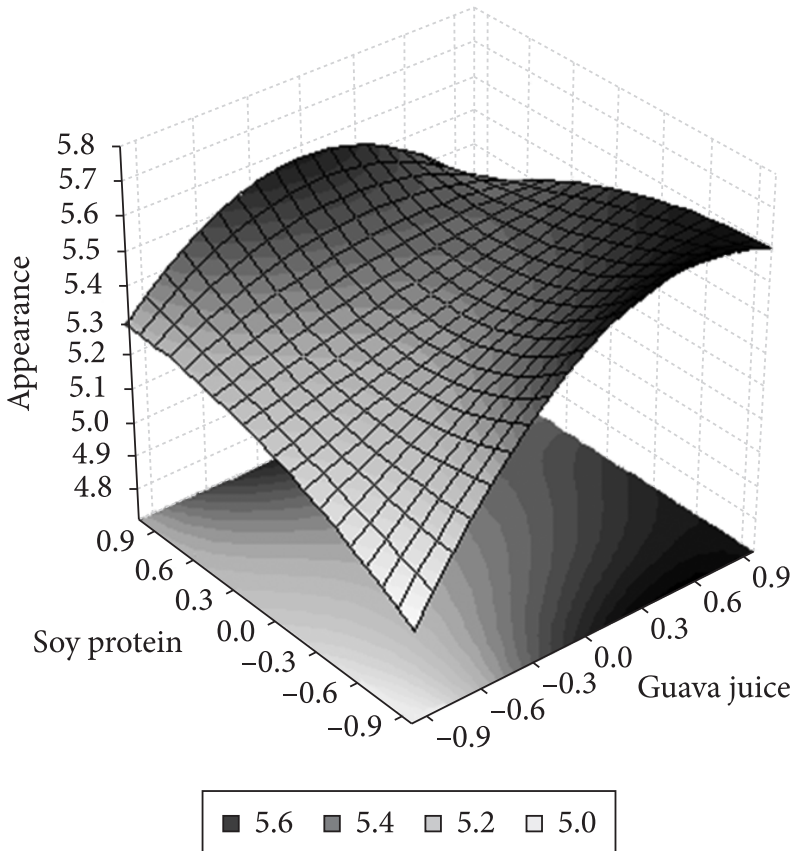

Figure 4. Effect of soy protein and red guava juice proportions on the degree of liking of soy-based emulsions. 
The regression models for acceptance and color could not be fitted satisfactorily to mathematical models due to low ( $1-55 \%)$ adjusted determination coefficients (data not shown), which means that the regression models could not define well the true behavior of the system (MYERS; MONTGOMERY, 2002). Therefore, those sensory data could not be used for RSM application. Low values of determination coefficients are frequent in sensory evaluations due to the subjective nature of the data (SHIHANI; KUMBHAR; KULSHRESHTHA, 2006), specially when consumers are used as panelists.

With regard to the appearance data, all assays garnered mean hedonic scores ranging from 'slightly liked' to 'moderately liked'. Sample F6 (1\% SP, 32\% GJ) was given the best score for this attribute, as seen in Table 4. The mathematical model fitted through RSM could explain $75.16 \%$ of the raw data and revealed that both soy protein and guava juice contents were responsible for the degree of liking of the appearance of the soy-based emulsions (Figure 4); however the linear and the quadratic effects of such ingredients were significant and had the tendency to decrease the mean score of such attribute.

Table 4. Sensory attributes of the developed soy-based emulsions

\begin{tabular}{|c|c|c|c|c|c|}
\hline \multirow[t]{2}{*}{ Assays } & \multicolumn{2}{|c|}{$\begin{array}{c}\text { Independent } \\
\text { variables }\end{array}$} & \multicolumn{3}{|c|}{$\begin{array}{c}\text { Sensory } \\
\text { attributes }^{1}\end{array}$} \\
\hline & GJ (\%) & SP (\%) & Acceptability & Color & Apperance \\
\hline 1 & 22 & 1.00 & $5.21^{\mathrm{b}}(0.86)$ & $5.01^{\mathrm{a}, \mathrm{b}, \mathrm{c}}(0.98)$ & $5.07^{\mathrm{a}}(0.66)$ \\
\hline 2 & 22 & 2.00 & $4.35^{\mathrm{a}}(0.77)$ & $5.08^{\mathrm{a}, \mathrm{b}, \mathrm{c}}(1.00)$ & $5.21^{\mathrm{a}, \mathrm{b}}(1.32)$ \\
\hline 3 & 22 & 3.00 & $5.56^{\mathrm{b}, \mathrm{c}}(1.01)$ & $4.99^{\mathrm{a}, \mathrm{b}}(1.01)$ & $5.19^{\mathrm{a}, \mathrm{b}}(0.89)$ \\
\hline 4 & 27 & 1.00 & $5.48^{\mathrm{b}, \mathrm{c}}(0.97)$ & $5.05^{\mathrm{a}, \mathrm{b}, \mathrm{c}}(0.97)$ & $5.48^{\mathrm{a}, \mathrm{b}}(0.69)$ \\
\hline 5 & 27 & 2.00 & $5.13^{\mathrm{b}}(0.94)$ & $4.80^{\mathrm{a}}(1.07)$ & $5.45^{\mathrm{a}, \mathrm{b}}(1.16)$ \\
\hline 6 & 27 & 3.00 & $6.00^{c}(0.82)$ & $5.49^{b, c}(1.13)$ & $5.64^{\mathrm{a}, \mathrm{b}}(0.66)$ \\
\hline 7 & 32 & 1.00 & $5.61^{\mathrm{b}, \mathrm{c}}(1.00)$ & $5.60^{c}(1.15)$ & $5.69^{\mathrm{b}}(0.77)$ \\
\hline 8 & 32 & 2.00 & $5.96^{c}(1.19)$ & $5.27^{\mathrm{a}, \mathrm{b}, \mathrm{c}}(1.28)$ & $5.49^{\mathrm{a}, \mathrm{b}}(0.81)$ \\
\hline 9 & 32 & 3.00 & $5.20^{\mathrm{b}}(1.01)$ & $5.00^{\mathrm{a}, \mathrm{b}}(1.20)$ & $5.19^{\mathrm{a}, \mathrm{b}}(0.56)$ \\
\hline $10(\mathrm{C})$ & 27 & 2.00 & $5.45^{\mathrm{b}, \mathrm{c}}(0.75)$ & $5.25^{\mathrm{a}, \mathrm{b}, \mathrm{c}}(1.04)$ & $5.31^{\mathrm{a}, \mathrm{b}}(0.73)$ \\
\hline $11(\mathrm{C})$ & 27 & 2.00 & $5.60^{\mathrm{b}, \mathrm{c}}(0.98)$ & $5.15^{\mathrm{a}, \mathrm{b}, \mathrm{c}}(1.12)$ & $5.31^{\mathrm{a}, \mathrm{b}}(1.02)$ \\
\hline $12(\mathrm{C})$ & 27 & 2.00 & $5.49^{\mathrm{b}, \mathrm{c}}(0.83)$ & $5.19^{\mathrm{a}, \mathrm{b}, \mathrm{c}}(0.89)$ & $5.37^{\mathrm{a}, \mathrm{b}}(1.20)$ \\
\hline \multicolumn{3}{|c|}{ Psample (Hartley) ${ }^{2}$} & 0.18 & 0.44 & 0.36 \\
\hline \multicolumn{3}{|c|}{ Psample (ANOVA) ${ }^{3}$} & $<0.001$ & $<0.001$ & $<0.001$ \\
\hline \multicolumn{3}{|c|}{ Ppanelist (Hartley) ${ }^{2}$} & 0.14 & 0.05 & 0.24 \\
\hline \multicolumn{3}{|c|}{ Ppanelist (ANOVA) ${ }^{3}$} & 0.06 & 0.05 & 0.07 \\
\hline
\end{tabular}

SP, Soy Protein; GJ, guava juice; (C), centre point; ${ }^{1}$ Data expressed by mean (SD) $(n=75)$; ${ }^{2}$ Probability value obtained by Hartley test (F max) for homogeneity of variances; ${ }^{3}$ Probability value obtained by two-way ANOVA; Different letters in the same column represent statistical different results according to the Tukey's test $(\mathrm{p}<0.05)$.

Table 5. Linear correlation between sensory and instrumental color parameters.

\begin{tabular}{lccc}
\hline \multicolumn{1}{c}{ Parameters } & Acceptance & Visual color & Appearance \\
\hline Lightness $\left(L^{*}\right)$ & 0.34 & 0.53 & 0.34 \\
$a^{\star}$ coordinate & 0.26 & 0.15 & 0.31 \\
$b^{*}$ coordinate & 0.08 & 0.43 & 0.23 \\
Hue angle $\left(h^{*}\right)$ & 0.08 & 0.01 & 0.27 \\
Chromaticity $\left(C^{*}\right)$ & 0.40 & 0.46 & 0.51 \\
\hline
\end{tabular}

All the Pearson coefficient products were not significant $(p>0.05)$.

\section{Univariate correlations}

As reported above in Tables 3 and 4 , significant differences between soy-based desserts were detected both by instrumental and by sensory methods. To explore the relationships between them, linear correlation analysis was used to establish associations between the sensory and the instrumental color parameters. The linear regression results (Table 5) showed that the correlations were not significant $(p>0.05)$. The only moderate-intensity correlations were obtained between chromaticity and appearance $(\mathrm{r}=0.51)$, and between color and lightness $(r=0.53)$, whereas the other parameters did not seem to be associated at all. This result indicates that there is a random, nonlinear relationship between the variables.

With regard to both sensory and instrumental color attributes, one main conclusion can be drawn: color attributes were not satisfactorily related to the sensory characteristics of the soy-based emulsions. This was due to the fact that sensory data are very subjective and depend on many psychological conditions and expectations from the untrained panelist. However, obtaining a significant and high value of a connection between instrumental and sensory analyses is not a simple task; it demands a lot of training of all subjects involved in the study, which is not practical in food companies.

A trained panel is more accurate when rating a hedonic scale and profiling the product in accordance with a certain attribute. In addition, a trained panelist is more suitable for giving judgments compared to a regular consumer that was not trained for profiling a food product (MACDOUGALL, 2002). Thus, it is not surprising that although using 75 untrained consumers our results did not correlate significantly to instrumental color attributes. Tárrega and Costell (2007) studied the sensory and instrumental color of dairy vanilla desserts and verified a significant positive correlation between sensory color and $a^{*}$ coordinate $(\mathrm{r}=0.89)$, and significant negative correlations with parameters $L^{*}$ and $h^{*}(\mathrm{r}=-0.96$ for both parameters). No significant correlations were found between sensory color data and $b^{*}$ or $C^{\star}$ parameters $(\mathrm{r}=0.32$ for either parameter). In contrast to these results, Granato, Freitas and Masson (2010), using an untrained panel, verified a strong and significant correlation $(r=0.92 ; p<0.001)$ between total color degradation and the degree of liking of the color of a sixty-day cold stored soy-based emulsion produced with $2 \%$ SP and $32 \%$ GJ.

\section{Conclusions}

Some conclusions can be drawn from this research: Emulsions that contained at least 2\% SP garnered hedonic scores above 5.00 for taste and acceptance suggesting that a palatable soy-based emulsion can be developed without enhancing the undesirable astringent flavor; The more GJ was added to the products, the higher the obtained scores for taste and color. Moreover, RSM showed to be an adequate approach for modeling the chromatic features of emulsions - redness and hue angle, and also the appearance of the developed products; Pearson correlations measurement was the univariate technique that highlighted correlations between instrumental and subjective data; When instrumental and subjective analyses are performed, 
it is important that the consumers used as panelists go through some training before evaluating food products, so the data will present less variability and RSM can be further applied; More studies must be carried out in order to characterize new soybased products, especially in sensory and chromatic aspects due to their importance for the consumer's acceptance.

\section{Acknowledgements}

We would like to thank CAPES for the Master scholarship (granted to Daniel Granato) and PPGTA/UFPR for all the support.

\section{References}

BARROS NETO, B.; SCARMINIO, I. S.; BRUNS, R. E. Como fazer experimentos. 3. ed. Campinas: Editora da Unicamp, 2007. $480 \mathrm{p}$.

BEHRENS, J. H.; ROIG, S. M.; SILVA, M. A. A. P. Fermentation of soymilk by commercial lactic cultures: development of a product with market potential. Acta Alimentaria, v. 33, n. 2, p. 101-109, 2004.

CALVO, C.; SALVADOR, A.; FISZMAN, S. M. Influence of colour intensity on the perception of colour and sweetness in various fruitflavoured yoghurts. European Food Research and Technology, v. 213, p. 99-103, 2001.

DUANGMAL, K.; SAICHEUA, B.; SUEEPRASAN, S. Colour evaluation of freeze-dried roselle extract as a natural food colorant in a model system of a drink. Food Science and Technology, v. 41, p. 1437-1445, 2008.

DUTCOSKY, S. D. Análise sensorial de alimentos. 2. ed. Curitiba: Champagnat, 2007.210 p.

GALLO, V. et al. Effect of storage on the phenolic content, volatile composition and colour of white wines from the varieties Zalema and Colombard. Food Chemistry, v. 13, n. 2, p. 530-537, 2009.

GRANATO, D. Emulsão de soja e goiaba: caracterização físicoquímica, cromática, sensorial, e de estabilidade. 2009. 169 f. Dissertation (Máster in Food Technology)-Universidade Federal do Paraná (UFPR), Curitiba, 2009.

GRANATO, D.; ELLENDERSEN, L. S. N. Almond and peanut flours suppelmented with iron as potential ingredients to develop glutenfree cookies. Ciência e Tecnologia de Alimentos, v. 29, p. 395-400, 2009.

GRANATO, D.; FREITAS, R. J. S.; MASSON, M. L. Stability studies and shelf life estimation of a soy-based dessert. Ciência e Tecnologia de Alimentos, v. 30, n. 3, p. 797-807, 2010.

HEREDIA, F. J. et al. A comprehensive study on the colour of virgin olive oils and its relationship with their chlorophylls and carotenoids indexes (II): CIELUV and CIELAB uniform colour spaces. Food Research International, v. 41, n. 5, p. 513-521, 2008.
HEREDIA, F. J. et al. Measuring colour appearance of red wines. Food Quality and Preference, v. 18, n. 6, p. 862-871, 2007.

HUNT, R. W. G. Measuring Colour. 3 ed. Fountain Press: London, 2001. 400 p.

HUTCHINGS, J. B. Color Measurements. Encyclopedia of Analytical Science, 2005. p. 198-208.

HUTCHINGS, J. B. Food color and appearance. 2. ed. Gaithersburg: Aspen Publishers, 1999. $610 \mathrm{p}$.

LAWLESS, H. T.; HEYMANN, H. Sensory evaluation of food: principles and practices. Gaithersburg: Aspen Publishers, 1999. $827 \mathrm{p}$.

MACDOUGALL, D. B. Color in food: improving quality. New York: Boca Raton, 2002. 388 p.

MELENDEZ-MARTINEZ, A. J. et al. Does the carotenoid neoxanthin occur in orange juice? Food Chemistry, v. 107, n. 1, 2008.

MELÉNDEZ-MARTÍNEZ, A. J.; VICARIO, I. M.; HEREDIA, F. J. Instrumental measurement of orange juice colour: a review. Journal of the Science of Food and Agriculture, v. 85, p. 894-901, 2005.

MYERS, R. H.; MONTGOMERY, D. C. Response surface methodology: process and product optimization using designed experiments. 2. ed. New York: Wiley, 2002.

NATH, A.; CHATTOPADHYAY, P. K. Optimization of oven toasting for improving crispness and other quality attributes of ready to eat potato-soy snack using response surface methodology. Journal of Food Engineering, v. 80, p. 1282-1292, 2007.

OSORIO, C. et al. Colour and flavour changes during osmotic dehydration of fruits. Innovative Food Science \& Emerging Technologies, v. 8, n. 3, p. 353-359, 2007.

POPPER, R. et al. The effect of attribute questions on overall liking ratings. Food Quality and Preference, v. 15, n. 7, p. 853-858, 2004.

RODRIGUEZ-AMAYA, D. B. A.; AMAYA-FARFAN, J.; KIMURA, M. Carotenoid composition of Brazilian fruits and vegetables. Acta Horticulturae, v. 744, p. 409-416, 2007.

SHIHANI, N.; KUMBHAR, B. K.; KULSHRESHTHA, M. Modeling of extrusion process using response surface methodology and artificial neural networks. Journal of Engineering Science and Technology, v. 1, n. 1, p. 31-40, 2006.

SOLER, L. Development of non-dairy frozen emulsion containing soy protein and coconut milk. 2005. $84 \mathrm{f}$. Thesis (Doctor in Food Science)-Louisiana State University and Agricultural and Mechanical College, Department of Food Science. Lousiana, 2005.

TÁRREGA, A.; COSTELL, E. Colour and consistency of semi-solid dairy desserts: Instrumental and sensory measurements. Journal of Food Engineering, v. 78, p. 655-661, 2007.

YAM, K. L.; PAPADAKIS, S. E. A simple digital imaging method for measuring and analyzing color of food surfaces. Journal of Food Engineering, v. 61, n. 1, p. 137-142, 2004. 